\title{
A Study on Customers Positive Attitude and Perception on Online Purchasing of Fashion Apparel
}

\author{
Nethravathi T. S. ${ }^{1}$ and G. S. Vijaya ${ }^{2}$ \\ ${ }^{1}$ Research Scholar, Department of Management Studies, Jain University, Bangalore, Karnataka, India. \\ ${ }^{2}$ Research Guide, Jain University and Associate Professor, COBA, A1, Yamamah University, Riyadh, \\ KSA.
}

CITATION: Nethravathi, T. S. and Vijaya, G. S. (2020), "A Study on Customers Positive Attitude and Perception on Online Purchasing of Fashion Apparel", MERC Global's International Journal of Management, Vol. 8, Issue 4, pp. 139-144.

ARTICLE HISTORY: Submitted: April 18, 2020, Revision received: May 22, 2020, Accepted: June 10,2020

ARTICLE TYPE: Research paper

\begin{abstract}
Electronic marketing is the new transformation in the ongoing years. Technology isn't just rising as one of the day by day schedules, for the associations yet for the customers moreover. Over the previous decade, the vast majority of the business associations are dashing with innovative change. The change of the customary business into the E-Commerce is profiting the Industries and in this way, the incomes and the economy of the nations are believed to reinforce. Industry specialists are flourishing to comprehend the client's behaviour and their frames of mind. The web-based shopping and marketing are reasonably clear to demonstrate the equivalent. Before long, the digitalism will turn into a heavy-handed dispersion channel for the lion's share of fruitful business visionaries. The organisations should initially focus on understanding the mentalities and behaviour of its potential customers who are the real purchasers with various decisions of web architecture and site unwavering quality/culmination however comparative assessments of site protection/security issues, which understood that security/security issues are the key impacting highlights to generally on the web purchasers. In this paper, we have presented the results of a questionnaire survey which has focussed on understanding positive attitude and perception on online purchasing of fashion apparels. A questionnaire survey has been carried out and the results were interpreted with the help of the IBM SPSS tool. It has been observed that customers have a positive attitude and perception on online purchasing of fashion apparel.
\end{abstract}

KEYWORDS: E-commerce, Perception, Attitude, Electronic marketing, Fashion apparel.

\section{BIBLIOGRAPHY}

1. ACNielsen (2007), "Perception towards online shopping: An empirical study of Indian Consumer", Abhinav National Monthly Refereed Journal of Research in Commerce \& Management, Vol. 3, Issue 1, pp. 202.

2. Agarwal, R. and V. Venkatesh (2002), "Assessing a Firm's Web Presence: A Heuristic Evaluation Procedure for the Measurement of Usability", Information Systems Research, Vol. 13, Issue 2, pp. 168186.

3. Bhattacherjee, Anol (2001), "Understanding Information Systems Continuance: An ExpectationConfirmation Model", MIS Quarterly, Vol. 25, Issue 3, pp. 351-370.

4. Chattaraj, Dibyendu and Mukherjee, Sujit (2019), "Impact of Gender on the Determinants of Purchase Intention of College Students toward Fashion Apparels", MERC Global's International Journal of Management, Vol. 7, Special Issue 1, pp. 146-153.

5. Nicolas, Ramírez (2010), Asian Journal of Management and Research, Vol. 3, Issue 2, pp. 396- 405.

6. Oliver, R. L. (1980), "A cognitive model of the antecedents and consequences of satisfaction decisions", Journal of Marketing Research, Vol. 17, Issue 4, pp. 460-469. 
7. Pooja; Mittal, Sanjiv and Kamakshi (2019), "A Study on Impulse Buying Behaviour of Consumers towards Apparels with reference to In-store Environment", MERC Global's International Journal of Management, Vol. 7, Issue 1, pp. 01-08.

8. Raturi, Sushil and Raturi, Rakhi (2019), "Impact of Brand Attributes on Consumers' Conative Attitude A Study for Indian Apparel Industry”, MERC Global's International Journal of Management, Vol. 7, Issue 4, pp. 307-312.

9. Rogan, Donald and Graz, FH Joanneum (2007), International Consumer Behaviour, 28 May - 1 June.

10. Sharma and Mittal (2009), "Prospects of e-commerce in India, Asian Journal of management and research", Asian Journal of Management and Research, Vol. 3, Issue 2, pp. 405-410. 